AÜIFD Cilt XLIV (2003) Sayı I s. 467-487

\title{
20. Yüzyılın İkinci Yarısında Din Sosyolojisi-ı
}

\author{
James A. BECKFORD \\ Çev.: İhsan ÇAPCIOĞLU
}

Ar. Gör., Ankara Üniversitesi İlahiyat Fakültesi

e-mail: icapci@divinity.ankara.edu.tr

\section{Giriş}

1945 'ten günümüze kadar din sosyolojisine yapılan zengin ve çeşitli katkıları bilen herkes, bu katkılar üzerine eleştirel, özlü ve objektif yorumlar yapmanın hiç de kolay olmadığını takdir edecektir. Gerçekte bu, pek çok nedenden dolayı caydırıcı bir iştir. Konunun sınırları içerisinde kalmanın zorluğu bir tarafa, din sosyologlarının büyük çoğunluğu tarafından kullanılan dilin dışındaki dillerde basılmış eserler ve bizzat din fenomeninin yanı sıra, din sosyolojisinde dağınık hâlde bulunan gelişmeler gibi çok daha zihin karıştırıcı problem karşısında karar vermek oldukça zordur. Başka bir zorluk ise, din konusunda genel sosyolojiden kaynaklanması muhtemel farklı anlayışlar ile din sosyolojisi arasında bir sınır çizmektir. Ayrıca, teorik düşünceler tarihi üzerine yazılıp çizilenlerin bolluğuna rağmen karşılaştırmalı bir din sosyolojisi tarihi henüz bulunmamaktadır. Şayet bu durum, din sosyologlarının kendi alt disiplinlerine ilgisizliğini gösterirse, muhtemelen

- Bu makale, alanında yaklaşık yarım asırlık bir geçmişe sahip olan uluslararası din sosyolojisi dergisi "Social Compass" da "The Sociology of Religion 1945-1989", 37 (1), 1990, pp. 45-64. başlı̆̆ı altında yayımlanmıştır.

' Bu makalenin ilk taslağının ortaya çıkması sırasındaki değerli katkılarından dolayı, Karel Dobbelaerc. François Houtart ve Bryan Wilson'a çok teşckkür ederim. 
bu, 1945 ve sonrası dönemde yoğun bir şekilde görülen maddî, entelektüel ve ideolojik ilgi alanlarındaki parçalanmaların bir sonucudur.

Bu tür ciddî problemlerle başa çıkmak için bu makalenin alanında bazı sinırlamalar yapmak zorunda kaldım. Ömeğin, burada ne sahasında en ünlü yayınların bir listesini, ne de mümkün olduğunca çok sayıda yayının kapsamlı bir özetini sunmaya çalışacağım. ${ }^{2}$ Ayrica bu, ne yeni modaya uygun olarak büyük katkılar sağlayabilecek teorik sentezler yapma girişimi (krş. Wuthnow, 1988), ne son kırk beş yıldan fazla bir zaman içerisinde din sosyolojisi adına yapılan muhtelif çalışmaların bir araya toplandığı ve ne de yeterince ilgi çekici eserlerin sadece kronolojik bir özetinin sunulduğu bir çalışmadır. Esasen burada uyguladığım metot; başlıca organizasyonlar, dergiler, perspektifler, konular, kavramlar, teoriler ve sosyolojik bakış açısıyla dîni anlama girişimlerinden kaynaklanan belli başlı sorunların, analitik ve seçmeci bir özetinin sunulmasından ibarettir. Bu şu anlama gelmektedir: Burada yazılanları; zaman, dil, ulusal sınırlar, teorik ekoller ve ampirik uzmanlık alanlarını içine alan bölümlere ayırdım ve bir soruyu sürekli zihnimde tutmaya çalış̧ım: İkinci Dünya Savaşı'nın sona ermesinden günümüze kadar geçen süre içerisinde dînin sosyolojik anlamında nasıl bir gelişme kaydedilmiştir? Ayrıca bu soru, sadece kavramsal, teorik, ampirik ve metodolojik sorunları değil; aynı zamanda sosyolojinin diğer alanları; genel toplum teorileri ve dînin sosyolojik bakış açısıyla incelenmesini etkileyen kurumsal şartları da araştırmaya dâhil etmeme imkân sağladı.

\section{Organizasyonlar}

Günümüzde din sosyolojisi, dînin sosyolojik yönlerini araştıran uzmanlardan oluşan sosyal ve kurumsal yapının henüz tam olarak yerleşmediği 1940'lı yılların ortaları ile kıyaslandı̆̆ında, entelektüel alan, akademik uzmanlık ve bilim adamları topluluğu olarak oldukça iyi durumdadır. Sosyoloji klasiklerinin sözde altın çağı olarak kabul edilen 19. yüzyıl ile 20. yüzyılın dönemecinde bazı ciddî paradigmatik çalışmalar ortaya konulmuştu. Ancak bu dönemi, Marx, Weber, Tönnies, Simmel ve Tröeltsch gibi çok az sayıda nitelikli bilim adamının yer aldığı uzun bir durağanlık dönemi izledi (Beckford, 1989) ${ }^{3}$. Fakat, yine bu dönemde, Halbwachs ve Mauss gibi pek çok bilim adamı Durkheimci bakış açısına dayalı çalışmalar gerçekleştirdi.

${ }^{2}$ Ancak, yeni yayınlar listesi için, Wach (1945), Le Bras (1956), Carrier ve Pin (1964), Desroche ve Seguy (1970), Montminy ve Crysdale (1974), Drehsen (1980), Dobbeleare (1981), Foucart (1982), Blasi ve Cuneo (1986), Homan (1986) ve Sociologia de la Religion y Teologia: Estudio Bibliograpia, Madrid: Instituto Fe y Secularid. Editorial Cuadernos para el Dialogo S. A.. 1975; ve idem., volume B, 1978'in yanı sıra; Religion Index One, Religion Index Two. Social Compass ve Archives de Sciences Sociales des Religions'a bakılabilir.

${ }^{3}$ Schreuder (1966) ve Seyfarth'a (1980) göre, bu durum, klasik cserlerin gerektiği gibi tercüme edilmemesinden kaynaklaniyordu. 
Bir çok ülkede modern din sosyolojisinin kurumsallaşmasına yönelik ilk hareket, çoğunlukla profesyonel sosyologlar, kilise yöncticileri ve çeşitli şekillerde dîni organizasyonlara katılan alan dışı bilim adamlarından geldi. ${ }^{4}$ 1940'larda bu "kilise benzeri" oluşumlar, sosyolojik bilginin uygulanmasından sosyal şartların iyileştirilmesine ve dînin amacına uygun olarak metodolojik tetkikinden sosyal yapılar ve süreçlere katkısına kadar bir çok konuda farklı eğilimlere sahip oldukları hâlde, gittikçe güç topladılar. Bu gruplar, daha sonra CISR' ' doğuran bir dernek olan Amerika Katolik Sosyoloji Derneği'nin (ACSS) kurulmasıyla faaliyet alanlarını genişlettiler. Ayrıca ayn model, 1953 yılında Hollanda (Goddijn ve Houtart, 1983) ve İspanya'da (Estruch, 1976) neşredilmeye başlanan Social Compass'ın (Sosyal Pusula) ${ }^{5}$ kurulması sirasinda da uyguland.

Farklı bir model ise, daha az reformcu bir bakış açısıyla dîni ele alan tarihçi, felsefeci, antropolog ve sosyologların 1950'li yıllarda ayrı ayrı birlikler kurmaya başladığı, Fransa, İngiltere ve diğer bazı ülkelerde görüldü. Örneğin, Dinler Sosyolojisi Grubu'nun (Groupe de Sociologie des Religions) beyin takımı Sosyal Pusula'dan çok daha az reformcuydu (Desroche, 1965). Bu durum, her ne kadar adı "reformcu" çağrışımlar yapsa da, Fransız Din Sosyolojisi Derneği (Association Française de Sociologie Religieuse) için de geçerlidir. Ayrıca, Fransız grupların tarihsel ve karşılaştırmalı perspektifi, dînin sosyolojik analizini, diğer insan bilimleri ve sosyal bilimlerden daha geniş bir çerçeveye yerleştirme eğiliminin bir göstergesiydi (Desroche ve Sequy, 1970) ${ }^{6}$. Savaş sonrası dönemde din sosyolojisine katkıda bulunan, sahasında aynı derecede eklektik birkaç Alman bilim adamı, (Wach, 1944, 1945; Mensching, 1947) Religionssoziologische Arbeitsgemeinschaft der Deutschen Gesellschaft für Soziologie'nin merkezinde yer alıyordu.

4 Gerçekte, Amerikan sosyolojisi, kuruluşunu ve ilk yıllardaki gelişimini, büyük oranda, dindarlıklarıyla ön plana çıkmış kişilere borçludur (bk7.. Vidich ve Lyman, 1985).

${ }^{5}$ Bu dergi, başlangıçta KSK] (Sosyo-Ruhani Katolik Enstitüsü) tarafından Hollanda'da çıkartılıyordu. Ancak, 1960 yılında, adı Social Conıpass olarak değiştirilerck, FERES'e (Uluslararası Din Sosyolojisi Enstitüleri Federasyonu) devredildi. Derginin yeni yönetim yeri, Brussels'te bulunan Sosyo-Dîni Araştırmalar Mcrkezi (The Center for Socio-Religious Research) olduğu hâlde, 1971-1988 yılları arasında Ottignies-Louvain-la-Neuve'de basıldı. Editörlüğünü, $1960^{\prime}$ dan $1968^{\circ} \mathrm{c}$ kadar W. Goddijn yaptı. 1968'den bu tarafa ise. F. Houtart yapmaktadır. Dergi, 1989 yılında Sage Yayınevi tarafından Londra'da basılmaya başlandı ve hâlâ Louvain-la-Ncuve'den yönctilmektedir.

"Desroche (1965:.3) Archives de Sciences Sociales des Religions' ın programını "inançlar ve ideolojiler üstü, uluslararast ve inter disipliner" olarak nitclendiriyordu. Paris Din Sosyolojisi Grubu, sadece, dine bilimsel anlamda ilginin artırılması konusunda değil; aynı zamanda Fransa ve okyanus ötesi ülkelerdeki dîni araştırmalar üzerine düzenlediği seminerler vasıtasıyla yaptığı katkılarla da adından söz ettirmeyi başarmıştır. Ayrıca bu grup, araştırma, yayın ve eğitim-öğretim faaliyetlerini aynı çatı alında toplamak amacıyla bir sosyal bilimler enstitüsü kurmayı düşünmüştür (Comite de Redaction. 1971). 
Bütün bunlardan başka Amerika Birleşik Devletlerinde dînin sırf sosyolojik tetkiki, üniversite dersleri, meslekî dernekler ve dergilerden oluşan çok daha dar bir çevrede yürütülüyordu (Moberg, 1966a). Bu tür daha seçkin ve metodolojik açıdan daha kompleks bir din sosyolojisinin gelişimi, dînin s1nırlı bir alandan taşınarak, ayrı bir sosyal kurum ya da herhangi bir insan topluluğunun sürekliliğini sağlayan ve çeşitli fonksiyonlara sahip bir sosyal organizasyon olarak tanımlayan formel ve yapısal-fonksiyonel bakış açılarıyla incelendiği daha geniş bir alanın kurulmasıyla sonuçlandı (bkz. Nottingham, 1954; O’Dea, 1966). Bu durum, dînin kısmî olarak izole edilmesine yol açan tarihsel, kültürel ve siyasî şartların etkisinden kurtarılarak nasıl sırf sosyolojik amaçlar için kullanılmaya başlandığını göstermektedir. Bu arada, Amerika Protestan Mezheplerinin, pazar araştırması ve idare bölümlerinde sosyolojinin kurumsallaşmasına yol açan bu tür kullanımlar, din sosyolojisi disiplininin özerkliğini zamanla pekiştirdi.

Temelleri papaz okulu toplantılarında atılan ve 1930'lu yıllarda Chicago bölgesinden gelen araştırmacılar tarafından kurulan Dîni Araştırmalar Derneği (RRA), siyasî eğilimi olan ve kiliseye yakın araştırmacılara yönelik bir platform olarak önemli bir görevi yerine getirdi (Hadden, 1974). 1938'de kurulan Amerika Katolik Sosyoloji Topluluğu (ACSS) ise, Latin kökenli Katolik araştırmacılar için benzer bir işleve sahipti. Ancak bu topluluk, Katolik sosyal politikasının tartışıldığı daha geniş bir platformdu. 1970 yılında ACSS'nin kozasından çıkan Din Sosyolojisi Derneği (Assocation for the Sociology of Religion)'nin kurulmasını muiteakip, Katolik sosyal politikası ve Katolik kilisesinin pratik problemleri, hem mezhep dışı ve hem de daha teorik temelli her türlü entelektüel problemin gündeme taşınmasıyla eski önemini kaybetti?

1955'te adını Bilimsel Din Araştırmaları Topluluğu olarak değiş̧iren, Bilimsel Din Araştırmaları Komitesi, teorik ve ampirik araştırmaların dengeli bir şekilde yürütüldüğgu kilise dışından ciddî bir bilimsel dernek olarak 1949 yılında kuruldu. Bu topluluğun disiplinler arası yaklaşımı, sadece Paris Dinler Sosyolojisi Grubu ve Quebec Laval Üniversitesi'nden bir grup bilim adamı tarafından paylaşıldı. SSSR; RRA ve ASR gibi gittikçe artan sayıda okyanus ötesinden gelen üyeye sahip olduğu hâlde, büyük oranda bir Amerikan organizasyonu olma özelliğini korumaktadır. Bu nedenle o, Amerikan Yüksek Eğitim Sistemi ve Amerika'daki büyük dinî organizasyonların kaynaklarını kendi lehine kullanmaktadır. Amerikan Sosyoloji Derneği'nde hiçbir zaman din ile ilgili bir bölümün bulunmaması; sadece diğer Amerikan organizasyonlarının işine yaramakta ve onların gün geçtikçe daha da güçlen-

7 Bazı açılardan, Hollanda Katolik Sosyo-Dîni Araştırmalar Enstitüsü'nün yaşadığı değişim, ACSS'nin 1945 yılında, o zamana kadar sürdürdüğü bütünüyle Katolik bakış açısını terk ettiği sırada geçirdiğj dönüşümü hatırlatmaktadır. Bu enstitü, katışıksız din sosyolojisi anlayışından hiçbir zaman vazgeçmediği hâlde, scküler sosyal araştırma enstitülerinin etkisiyle zamanla önemini kaybetmiştir (Lacyendecker, 1967). 
mesine katkıda bulunmaktadır. Diğer taraftan, Uluslararası Sosyoloji Derneği'nin 22 komisyonunun hiçbirinde din sosyolojisi bu tür kaynaklar arasında sayılmamaktadır. Ayrıca dernek, kurulduğu tarih olan 1950'li yılların sonlarından günümüze kadar, dört yılda bir düzenlenen Dünya Sosyoloji Kongresi ve dergi neşriyatı da dâhil hiçbir faaliyeti desteklememiştir ${ }^{8}$. Özetle, muhtelif bakış açılarıyla dîni ele alan meslek ve kilise gruplarının ortaya çıkardığı din sosyolojisinin, spesifik bir uzmanlık alanı haline gelmesi uzun zaman almıştır.

\section{Dergiler}

Bu meslekî ve disipliner gelişmeler, periyodik yayınların yörüngesini belirlemektedir. Social Compass 1953'te yayın hayatına başladı. Ancak, 1960'ların başına gelinceye kadar bütünüyle Katolik karakterini korudu. Hem Dinlerin Sosyal Bilimleri Arşivleri (Archives de Sciences Sociales des Religions) hem de Bilimsel Din Araştırmaları Dergisi (Journal for the Scientific Study of Religion) disiplinler arası özelliğini sürdürmeyi başardı. Amerika Katolik Sosyoloji Dergisi'nin (American Catholic Sociological Review) 1965'te adını Sosyolojik Analizler (Sociological Analysis) olarak değiştirmesi, kilise dergisi görünümünden profesyonel bir dergiye geçiş olarak önemli bir gelişmeydi. Italyan Din Sosyolojisi Dergisi (Sociologia Religiosa) 1960'ların başlarında yayın hayatına girmesine rağmen, gelişimini tamamlayamadı. Benzer bir şekilde Kuzey Amerika'da gittikçe artan sosyolojik din araştırmaları için alelacele kurulan Bilimsel Din Araştırmaları Dergisi (Journal for the Scientific Study of Religion)'nin hemen ardindan piyasaya çıkarılan, ancak özellikle, sosyolojik makaleler açısından Avrupa' da yeterli bir pazar oluşturamayan Internazionales Jahrbuch für Religionssoziologie (1965-1973) de kısa ömürlü oldu. İngiltere Din Sosyolojisi Yıllı̆̆gl [The Sociological Yearbook of Religion in Britain (1968-1975)] kısa sürede filizlendiği hâlde, bir süre sonra, İngiliz Yüksek Eğitimi'nin bir akademik uzmanlık alanı olan sosyoloji ile aynı kaderi paylaşarak hüsrana uğradı. Dinîn Sosyal Bilimleri Ylllik Dergisi [The Annual Review of the Social Sciences of Religion (1977-1982)] Avrupa'da Din Sosyolojisi için pro-

${ }^{8} 1956$ ve 1959 Dünya Sosyoloji Kongresi'nde din sosyologlan, kendi aralarında küçük bir toplantı tertiplediler. Daha sonraki toplantılarda katılımcılar, sonraki kongrede "bir din sosyolojisi grubunun" kurulması için Uluslararası Sosyoloji Derneği Idare Komisyonu'na dilekçe verdiler (Bimbaum, 1960: 112). Grubun başkanlığına Le Bras; sekreterliklerine ise, Bimbaum ve Desroche tayin edildi. 1961 yılında, Oxford Nuffield Üniversitesi'nde yapılan küçük çaplı bir toplantı, uluslar arası işbirliğini hızlandırdı. Ayrıca, bu toplantıda. 1962 Dünya Sosyoloji Kongresi'nin gündemi de kararlaştırıldı. RRA ve SSSR'nin işbirliğiyle Washington Georgetown Üniversitesi'nde düzenlenen bir sonraki kongrede, 83 delege ve 30 ziyaretçinin katıldığı ve üç gün süren toplantılar yapıldı (Shippey, 1962). Evian'da toplanan 1966 Dünya Kongresi'nde ise, Din Sosyolojisi Araştırma Komisyonu dört oturum tertip etti. Bu oturumlarda sunulan 22 tebliğin de ağırlıklı konusu sosyo-dîni değişme idi. 
fesyonel bir pazar yaratmayı başaramadı ve bir diğer kısa ömürlü girişim örneği oldu. Bu konuda en son katkıy ise, İtalyan dergisi Religione e Societa yaptı.

Kuzey Amerika'da çıkan Sociological Analysis, Journal for the Scientific Study of Religion, Review of Religious Research ve Sciences Religiouses'in sürekli artan tirajı ile karşılaştırıldığında kısmen daha az tiraja sahip olan Social Compass, Archives de Sciences Sociales des Religions ve Avrupa'da neşredilen en az dört dergi başarılı bir grafik sergileyemedi. Ayrıca, bir süre önce Amerikalı yayıncılar, din sosyolojisi alanında yeni kitap serileri ve yıllık periyodikler yayınlamaya başladılar'. Garland ve Greenwood yayınevleri din sosyolojisi ile bağlantılı konularda seçkin eserler neşretmeye devam ediyor. Sonuç olarak, bugün Kuzey Amerika'da birkaç bilgisayar destekli veri tabanı, faaliyet listesi ve yayın evi özeti, din hakkında sosyolojik bilgilerin yayılmasına yardımcı olmaktadır.

Diğer taraftan, birkaç nitelikli dergi ve yayın evi birlikte hareket ederek böylesine önemli bir fenomenin gölgede bırakılmasına seyirci kalmamalıdır. Bu noktada, genel sosyoloji dergilerinde din sosyolojisi alanında neşredilen makalelerin yoğunluğunda bir azalma görüldüğunü de eklemek istiyorum. Söz konusu dergilerden bazıları şunlardır: American Journal of Sociology, Revue Française de Sociologie, Canadian Journal of Sociology, Kölner Zeitschrift für Soziologie ve Rassegna Italiana di Sociologia. Bu durum, din sosyologlarının makalelerini yayınlamak için özellikle alanlarındaki dergi ve koleksiyonlanı tercih ettiklerini göstermektedir. Belki de bu, alan dışından bir kısım sosyologun din hakkında yazılan makalelerin dergilerinde neşredilmesine pek sıcak bakmadıklarının da bir göstergesidir. Ancak, gerekçesi ne olursa olsun, bu olay, din sosyolojisi alanının meslekî duruşunu açıkça gözler önüne sermektedir. Ayrıca, din sosyolojisinin film, televizyon ve hatta fotoğraf aracılığıyla yayılmasını amaçlayan birkaç girişim önemli görülebilir. Sözde, görsel sosyolojinin popülaritesi artmıştır. Ne var ki, bu durum, bilimsel ve popüler düzeyde din sosyolojisine hemen hemen hiç katkıda bulunmamıştır.

Sonuç olarak, din sosyolojisi derslerine kayıt yaptıran öğrencilerin elinde sayısız ders kitabı ve yayınlanmış metinlerden oluşan koleksiyonlar bulunmasına rağmen, bu derslerin içerikleri ve yapısı hakkında çok az şey bilinmektedir". Din sosyolojisi öğretimi ile ilgili Amerikan Sosyoloji Derneği'nin yıllık toplantılarında ara sıra yapılan atölye çalışmalarının dışında, bu tür problemlerin tartışıldığı profesyonel toplantılar çok nadir düzenlen-

y (1) M. L. Lynn ve D. O. Moberg (editörler), Research in the Social Scientific Study of Religion, Greenwich. CT: JAI Yayınevi. (2) D. B. Bromley (editör), Religion and the Social Order, Greenwich, CT: JAl Yayınevi. (3) editörlüğünü W. Clark Roof'un yaptığı yeni seriler.

10 Ancak, Adriance ve Blanshard (1987) Amerika Sosyoloji Derneği için din sosyolojisi özetleri derlemiştir. 
mektedir. Bir alt disiplin olarak din sosyolojisi, akademik konumu ve kullandığı yöntemler açısından kısmen kendi özünden uzaklaşmıştır. Kendine has metodolojik yöntem ve tekniklerin yetersizliği, alt disiplinlerin akademik itibarını gittikçe azaltmaktadır.

Özetle, Kuzey Amerika dergileri gelişimini sürdürürken, Avrupa dergileri karışık duygular içerisindedir. Ayrıca, başarılı din sosyolojisi dergileri nitelikli makaleleri genel sosyolojinin ilgi alanından kendi alanlarına çekmeyi başaramamıştır.

\section{Uluslararası Perspektifler}

Yaklaşık yirmi yıl önce (1968) K. Dobbelaere, Avrupalı meslektaşları çok daha "sosyo-rûhânî" sorunlarla ilgilenirken, Amerikalı sosyologların din ile diğer sosyal kurumlar arasındaki ilişkiler üzerine kafa yorduğunu gözlemlemişti. Başka yorumcular ise, Amerikalıların ampirik ölçümlere ağırlık verdiğini, Avrupalıların ise, teorik, felsefî ve tarihi yaklaşımlara yöneldiğini söylemişti (Moberg, 1966b). Bu durum günümüzde hâlâ geçerliliğini sürdürmesine rağmen, iki taraf arasında belli oranda karşılıklı etkileşimden söz edilebilir. Ancak, bana göre, etkileşimin yönü batıdan doğuya doğrudur ve etkisi $1960^{\circ}$ ların ortalarından beri, İngiliz ve AngloSakson kökenli Kanadalılardan gelen bilimsel katkılarla gittikçe artmaktadır. Bununla birlikte, Amerikalı sosyologların din sosyolojisinin Avrupa'daki gelişiminden haberdar olma düzeylerinin son derece düşük olduğu görülmektedir".

Fakat, hâkim rüzgarların Atlantiği aşan etkisi, uluslararası sosyolojik faaliyetlerin sadece bir örneğini oluşturmaktadır. Aynı derecede dikkat çekici bir diğer örnek ise, 1970'li yılların başından itibaren Japonların din sosyolojisine yaptığı katkılardır (Yonogawa ve Abe, 1977 ) ${ }^{12}$. Ayrıca, Latin Amerika ve özellikle Brezilya'da din sosyolojisi konusunda az sayıda uzman, bazı ilgi çekici araştırma problemleri ortaya atarak. Belçikalı ve Fransız bilim adamları ile birlikte çözümlemeler yapmıştır. Günümüzde Doğu Avrupa ülkelerinde de aynı şekilde ilginç ve sofistike araştırmalar gerçekleştirilmektedir. Artık temel problematik, devlet sosyalizmi altında dinî bilincin ve pratiklerin korunması değil, bundan çok daha önemlisi dinî bilincin ve dinî kurumların resmî ideolojilerle yan yana varlığını sürdürebilmesidir. [Bkz. Archives de Sciences Sociales des Religions 61 (1), 1988]. Ancak, Sri Lanka (Houtart, 1967; Gombrich, 1971) ve Güney Afrika Cumhuriyeti (Reinders ve Welz, 1972) hariç, Güney Asya ve Afrika'da sosyolojik din araştırmaları 1960'lardan bu yana, bu tür ciddî gelişme

"Aslında, Henri Descroche'un 1950'li yılların sonlarında Archives de Sciences Sociales des Religions'da düzenlenen SSSR toplantılarında sunulan tebliğlerin basılmasını teklif etmesi, atlantik ötesi bağlantıların gcliştirilmesi için iyi bir fırsattı. Ancak, bu öneri kabul görmedi.

12 Japonların din sosyolojisiyle gittikçe daha fazla ilgilendiğinin bir göstergesi, CISR' in 1978 yılı bölgesel toplantısını Japonya'da gerçekleştirmesiydi (CISR, 1978). 
belirtileri sergilememiştir. Özellikle, antropolojik yaklaşımların ağır bastığı Hindistan dinlerinin durumu ilgi çekicidir ${ }^{13}$.

Kendi ülkelerinde ve değişik ulusların kültürlerinde yerleşik hâlde bulunan en köklü dinî fenomenlerle yüzleşmek, çalışmalarını farklı ve özgün yöntemlerle geliştirmeye çalışan din sosyologları için hiç de şaşırtıcı olmamıştır. Örneğin, karakteristik olarak, İtalyanlar Katolisizmin siyasî yorumlarına; Japonlar, halk dinlerine ve yeni dinlere; İskandinav bilim adamları, popüler dinlere ve halk dinlerine; Hollandalılar ve Belçikalılar, önemli kişileri ve din adamlarını etkileyen olaylara; Almanlar, kilise organizasyonlarına ve Fransızlar ise, teorik fikirlerin ve ekümenizmin tarihine karşı oldukça duyarlıdırlar ${ }^{14}$. Günümüzde Amerikalı bilim adamlarının, din ve diğer sosyal sistemler arasındaki fonksiyonel ilişkiler üzerine gerçekleştirdiği araştırmalar, eskisi kadar dikkat çekici oranlara ulaşmamaktadır (Schreuder, 1966: 210-11). Ancak, 1960'lı yıllardan beri, İngilizler, çoğunlukla katılımlı gözleme dayalı olarak yürüttükleri ampirik araştırmalar kadar, büyük teorik sorunlara da yer vermektedirler (Martin, 1967).

Ayrıca, yaklaşık çeyrek asırdır gündemde olan farklılaşma sürecine ilaveten, din sosyologlarının kendi aralarındaki kültürel farklılıklar da bir dereceye kadar varlığını sürdürmektedir. Bu noktada, din sosyolojisi alanında gün geçtikçe artan faaliyet yoğunluğunun beraberinde getirdiği ihtisaslaşmaya da değinmek istiyorum. Din sosyolojisinde, örneğin, bir hastalık ve sağlık sosyolojisi ya da eğitim sosyolojisi kadar hızlı bir gelişme kaydedilmediği hâlde, bu alanda artan neşriyatla birlikte ciddî bir ihtisaslaşma eğilimi görülmüştür. Bu nedenle, kümülatif bilginin çokluğu yeni başlayanların gözünü korkutabilir. Gerçekten de, bilimsel faaliyetin diğer alanlarında olduğu gibi, din sosyolojisi alanında da akademik bilginin hacmi ve yayılımı her geçen gün artmaktadır. Bununla birlikte, bazı bilim adamları din sosyolojisinin diğer sosyoloji bölümlerinden tecrit edilmesini bile kayg1 verici bulurken (Beckford, 1985), diğer bazıları, "bilgi fazlalığından" şikayet edebilmektedir (Laeyendecker, 1984).

Ayrıca, sosyolojik bakı̧̧ açısının, teoloji, kilise tarihi ve dinler tarihi gibi komşu alanlar tarafından zamanla kabul görmesi, din sosyolojisinin sosyoloji ve diğer sosyal bilimler içindeki statüsünü yükseltmiş gibi görünmüyor. Örneğin, diğer sosyolojik araştırmalara ayrılan fonlarla karşılaştırıldığında, din sosyolojisine ayrılan fonların artırılıp artırılmaması 1960'lı yıllardan günümüze kadar sürekli tartışma konusu olmuştur. Bu fonların yetersiz olma nedenlerinden biri, ekonomik gelişme ve devletin kontrol görevleri üzerinde doğrudan etkisi görülmeyen bir kurum olarak dînin,

\footnotetext{
${ }^{13}$ Hindistan'ın büyük dinleri üzerine yapılan sosyal bilim araştırmalarının bir listesi için bkz. Visnanathan (1986).

${ }^{14}$ Diğer taraftan, ulusal farklılıkları bir kenara bırakarak, ortak ilgi alanları oluşturmayı başaran, Colloque franco italien d'Histoire et de Sociologie religieuse ve the Association suisse des Sociologues de la Religion (Campiche, 1971) gibi küçük oluşumlar vardır.
} 
araştırma fonları açısından sınırlandırılmaya müsait bir konu olarak değerlendirilmesidir. Bu durumun diğer bir nedeni ise, din gibi kültürel olarak yoğun ve içinde bulunduğu çevre ve sosyal şartlara bağlı bir fenomen üzerine kültürler arası araştırmalar gerçekleştirmenin doğasından kaynaklanan zorluktur.

\section{Konular ve Kavramlar}

Din sosyologlarının "din" kavramının anlamını hâlâ tartışmaya devam etmesi, kavramsal ayrıcalık ve haklılık iddiaları karşısında sağlıklı bir şüphecilik belirtisi olarak değerlendirilebilir (Hervieu-Leger, 1987). Bu tartı̧̧ma, antropoloji ve dîni araştırmalar ya da dinler tarihi alanlarında uzun ve yoğun bir geçmişe sahip olmadığı hâlde; bir çok din sosyologunun din kavramını, ampirik amaçları ve özellikle de alan araştırmaları ve diğer dîni tecrübe ile ilgili araştırmalar için kullanması, din sosyolojisi alanına has bir özelliktir. 1960'larda, özellikle ABD'de, dînin sosyolojik boyutlarının araştırılması, genel bir eğilimdi. O zamanlar, sosyolojik araştırmalar her konuyu ele alabilecek saygınlığa sahipti. Aslında, dînin boyutları üzerine yapılan araştırmalarla, örtülü bir şekilde din kavramının anlamını sınırlandırmayı amaçlayan girişimler arasında güçlü bir bağlantı vardır. Her iki süreçte de, kollektif bir fenomen olarak dînin kültürel ve toplumsal önemi genellikle göz ardı edilmiştir. Dînin, toplumdan yalıtılmı̧ bireylerin sözlü ifadeleri ve inançlarından hareketle incelenmesi ve "dindarlığın" sadece bireysel kimlik, duygu ve temayüller aracılığıyla tespit edilmeye çalışılmasının doğal bir sonucu olarak, dînin anlamında ciddî bir daralma meydana gelmiştir.

Beklentilerin aksine, bugün bir taraftan 1970'ler öncesinde rastlad1ğımız kilise güdümlü din sosyolojisi anlayışından gittikçe uzaklaşılırken, diğer taraftan dînin; genel, geleneksel, yaygın, halk, örtülü ve popüler tanımlarının beraberinde getirdiği çeşitlilik, bu kavramın anlamını daraltma girişimlerini olumsuz yönde etkilemektedir. Dînin bu tür kapalı ve son derece çeşitli görünümleri üzerine yapılan araştırmaların -bütün belirsizlik ve iç tutarsızlıklarına rağmen- ortak değer, duygu ve inançların varlığını ve önemini ortaya çıkarması, kollektif anlam ve hatta eylemler için ortak bir zemin oluşturacak gibi görünmektedir (bkz. Pace, 1987; Cipriani, 1989). Örneğin, hac konusunun zamanla sosyologların dikkatini çekmesi; İkinci Vatikan Konsili'nin bu konuda kilise dişındaki halka son derece dikkatli bir cevap vermesine ve hatta bir süre sonra papalıktan yazılı bir açıklama yapılmasına neden olmuştur [bkz. Social Compass 29 (1), 1982 ve 36 (2), 1989].

Dîni organizasyonları marjinalleştiren kurumsal farklılaşma sürecine rağmen, modern toplumlara dîni değerlerin kılavuzluk ettiğini savunan yapısal fonksiyonalistlere göre; büyük oranda Amerikalı sosyologların ilgi alanına giren sivil din kavramı, "yarım kalmış işlere" bir tür geri dönüşü temsil etmektedir. Aslında bu kavram, modernizmin kendi kendini yok etmesine engel olmak için ortaya atılmış, literal ve simgesel anlamlara sahip 
bir tür deus ex machina'dır. Sivil dîni söylemin hâlâ incelenmeye değer ideolojik sonuçları olduğu hâlde, bu tür tartışmalar, yapısal fonksiyonalistler dışında çok az kişinin ilgisini çekmektedir.

Diğer taraftan, politika ve din; iktidar ve din ile, kiliseler ve devlet arasındaki karmaşık ilişkilerin sosyolojik anlamı konusunda zamanla ciddî gelişmeler kaydedilmiştir (örneğin, bkz. Robbins ve Robertson, 1987). Bunlar, 1960'lardan önce dinle ilgili tartışmalarda rastlamadığımız, ancak daha sonraları sosyoloji literatürüne giren önemli konulardır ${ }^{15}$. Bu konular, başlangıçta fonksiyonalist perspektifle din hakkında yapılan tartışmalarda görüldü. Ancak, sonradan sivil haklar mücadelesi, nükleer güç, savaş, çevre kirliliği ve iktidar aleyhine düzenlenen kampanyalarda kullanılmaya başlandı. Son günlerde ise, özellikle din ve politika meselelerinin, bazı Marksist ve muhafazakarların gözündeki değeri gittikçe artmaktadır. Hindistan, $\mathrm{Ku}-$ zey Irlanda, İsrail ve Sri Lanka'daki din kaynaklı çatışmalar kadar, İslâm toplumlarının siyasî istikrarsızlığı da bu konulara ilgiyi alevlendirmektedir. Ancak, Afrika, Kuzey Amerika ve Latin Amerika'da devlet ile dîni organizasyonlar arasındaki gergin ilişkilerin her geçen gün şiddetini artırması, modern dînin kamusal görünürlüğünün azaltılmasına yönelik bazı keskin düşüncelerin ortaya çıkmasına neden olmuştur. Sonuçta, ulus devletlerden kurulu dünya sisteminde dînin önemi konusunda yapılan tartışmalar, yeniden ilgi odağı hâline gelmiştir. Din ve iktidarlar arasındaki yakın ilişkiye gösterilen duyarlılık bütün bunların açık kanıtıdır (Beckford, 1983).

Diğer birkaç konu, resmî ya da kurumsallaşmış din ile ilgili kaygıların ötesinde bir değişimi desteklemektedir. Bu durum, bir taraftan, dindeki parçalanmayı (Bibby, 1987), diğer taraftan ise, sosyologlar arasında dine karşı ilginin resmî dîni organizasyonların sınırlarını aştığını göstermektedir. 1960' ların sonlarında tarikat grupları ile büyük kilise ve mezhep hareketleri üzerine yapılan araştırmalarda, kısmen fenomenolojik ve dilsel etkilerin bir sonucu olarak, din değiştirme, taraftar toplama ve diğer dinlere karşı tahammülsüzlük gibi konuların öne çıtığı görülmektedir. Bu tür özel ihtisas gerektiren alanlar, toplum teorilerinde değişen ilgilere paralel olarak zamanla gelişimini sürdürmüştür. Bir dereceye kadar mahrumiyet ve gerilim psikolojisi üzerine kurulu olan determinist yaklaşımlar, yerini, din değiştirenlerin çok daha eylemci ve yaratıcı imajlarını destekleyen yorumlayıcı yaklaşımlara bırakmıştır (Barker, 1984; Snow ve Machalek, 1984; Richardson, 1985). Aynı derecede mikro sosyolojik eğilimler ise, Anglo-Sakson ve Fran\$ı sosyolojisi ile aşağı yukarı aynı dönemde gelişimini tamamlayan günlük hayat araştırmalarında görülmektedir. Önceki gelişmeler, analitik felsefeden kaynaklanırken, sonrakilerin kökeni histografi bilimidir. Ancak, her ikisi de, popüler ve örtülü din araştırmalarına kaynaklık etmiştir. Is Bu konular, Pope (1942), Yinger (1946) ve Fogarty (1957) gibi, öncmli istisnalar içermek-
tedir. 
1970'lerde, sayısız yeni dîni hareket ya da "yeni dînin" ortaya çıkışıyla birlikte yaşanan kısa süreli kesinti, aynı zamanda savaş sonrası dönemde din sosyolojisini harekete geçiren en önemli gelişmelerden biri olmuştur. Bu hareketlerin kaynağı, öğretileri, teşkilat yapıları ve üyeleri üzerine yapılan ilk araştırmalar (Wallis, 1984), hareket üyelerinin katıldığı tartışmaların yanı sıra, siyasal gelir kaynakları ve eski üyelerinin durumunu da gözler önüne seriyordu (Robbins, 1988). Sanayi toplumlarında bu tür fenomenleri önceden haber veren ve bunlar üzerine açıklamalar yapan din teorileri oldukça azdı. Çünkü, bu hareketlerin "gerçek" dîni temsil etmediğine inanılıyordu. Dolayısıyla, din sosyologları onları, fazlaca dikkate değer bulmadılar.

Yeni dîni hareketlerin ortaya çıktığı sıralarda dünyanın dört bir yanındaki sayısız kilisede karizmatik canlanmalar görülmeye başlandı. Sonuçta, pentakostalizm fenomeni üzerine yapılan sosyolojik araştırmalar, dîni liderliğin dinamikleri (Lalive d'Epinay, 1969), muhafazakar dinlerle sîyasi yönetimler arasındaki ilişkiler (Willems, 1964), pentakostalizmin göçmen ve marjinal bireyleri kazanma yöntemleri (Poblete, 1960) ile ruhsal ve fiziksel mutluluk arasındaki ilişki gibi konularda değerli bakış açılarını beraberinde getirdi. Gelişmekte olan ülkelerdeki dîni hareketlerle ilgili benzer araştırmalar ise, (Pereira de Queiroz, 1981), dîni canlanmanın ve din ile siyasî ya da ekonomik gelişme arasındaki ilişkilerin daha iyi anlaşılmasına katkıda bulunmuştur.

1970'lerin sonunda Hrıstiyanlık ve İslâmiyet'te yeniden canlandırılan fundamentalizm olgusu, din sosyologlarının zihnini meşgul etmeye devam etmektedir. Ayrıca bu konu, gazeteciler ve diğer sosyal bilimciler arasında da eskisinden çok daha fazla ilgi uyandırmaktadır. Bu fenomen, modern din teorilerini, bazı sosyologların dinden ziyade politikadan kaynaklandı̆̆ını düşündüğü günümüz problemleriyle aynı noktada buluşturdu. Esasen bu olgu, yeni dîni hareketler, ruhçuluk ve pentakostalizm gibi, modernizm ve dünya düzeni üzerine yapılan tartışmaların yanı sıra, politik sosyoloji ve suç sosyolojisindeki kavram ve teorileri de içine alan pek çok konudaki peşin hükümlerimize meydan okumanın avantajlarından yararlanmıştır.

Sonuç olarak, günümüzde bazı din sosyologları, kitle iletişimi, sağlık, dine dair biyo-etikler ve muhtelif dîni organizasyonlarda kadının statüsü gibi konularda araştırmalar yaparak diğer sosyoloji disiplinleriyle daha sıkı bağlantılar kurmaya başlamıştır. Burada özetlemeye çalıştığım çağdaş konular, 1940 ve 1950'li yılların din sosyolojisinde öne çıkanlarla kıyaslandığında, o dönemlerdeki birçok konunun tarihe karıştığı görülmektedir. Bunlar arasında, özellikle, kilise hizmetleri, Hrıstiyan demokrasisi, mezhep teorileri ve kilise araşırmaları gibi dîni organizasyonlarla ilgili araştırmaların yanı sıra, din ve aile kurumu, millenarizm, dinsizlik, Yahudilik, din ve sosyal hareketlilik ile Protestan ahlâkı tezleri yer almaktadır. Bu konular hâlâ merak uyandırmaya devam etseler de, din sosyolojisi alanında yapılan çalışmalar toplamı içersindeki oranları fazlasıyla azalmıştır. 
Esasen, konuları itibariyle diğer sosyoloji disiplinlerinden hiçbir farkı olmayan din sosyolojisi, kendi iç mantığından ziyade dîni fenomenlerin mütemadiyen değişen karakteri tarafından yönlendirilmeye devam etmektedir. Bu durum onun, içinde bulunduğu sosyal çevrenin etkisi altında olduğunun açık bir göstergesidir. Diğer taraftan, din sosyolojisi, dinde meydana gelen değişimlere ayak uydurabilmek için bakış açısını sürekli yenilemek zorundadır. Sonuç olarak, bu alanda, çok az sayıda formel teori ve çok miktarda kurgusal (ex post facto) düşünce vardır.

\section{Teorik Perspektifler}

1945 'ten günümüze kadar tüm teorik perspektifleri ve değişimleri değerlendirmemiz mümkün değildir. Burada sadece, en çok kullanılan kavramlarla ilgili teorilerde meydana gelen belli başlı değişiklikler gösterilmeye çalışılacaktır.

1. Kanaatimce, "La Sociologie Religiuse"ye, sadece savaş sonrası dönemde rastladığımız ilk ciddî akımı temsil ettiği için değil, aynı zamanda dînin sosyal pratiği üzerine bugün bile tartışılmaya devam eden sorular ortaya attığı için hak ettiği en yüksek mevki verilmelidir ${ }^{16}$. Hakikaten bu konuda, Georges Balandier, Fernand Boulard ve Gabriel Le Bras'a minnet borçlu olduğumuzu kabul etmeliyiz. Onların dîni pratiklerin değişen dağılımı, Katolik kilisesinin gelişimi, din ve siyasal ideolojiler arasındaki tarihsel bağlantılar gibi konulara yönelik entelektüel ilgileri, pek çok teorik araştırmaya öncülük etmiştir (Boulard ve Remy, 1968). Ayrıca onlar, özellikle, Fransa, Belçika, İspanya ve Hollanda gibi ülkelerdeki sosyologlar arasında din sosyologlarının öneminin artmasına güçlü bir şekilde katkıda bulunan metodolojik ilkeler ortaya koydular. Ancak, çok kaliteli Fransız şarapları gibi, "la sociologie religiuse" de çok iyi bir yolculuk yapamad1".

2. Başka bir büyük din sosyolojisi akımı ise, Talcott Parsons ve birkaç eski öğrencisinin savunduğu yapısal fonksiyonalizmdir. Bu akım din sosyolojisi alanında, tüm sosyal bilimlerin yanında, modernizmin sentetik ve yerli teorisini kurmayı hedefleyen daha geniş bir harekete dolaylı yönlerden katkıda bulunmuştur. Yapısal fonksiyonalistler, hızlı ekonomik gelişmenin yönü, demokrasi politikaları, çoğulcu kültürler ve "bağımlı" kişilik türlerinin etkisi altındaki modern ve modernleşmekte olan toplumlarda dinîn icra ettiği

16 Aslında, H. Paul Dauglass'ın 1920'ler Amerika'sında bu tür araştırmalara öncülük ettiğini iddia edenler vardır. Sanırım bu iddialar, onu, "Kilise'nin sınırlarını Genişletme Hareketi'nin" müjdecisi olarak göstermek isteyenler tarafından ortaya atılmaktadır

17 "Yolculuk sırasında kırılmadığı ya da çalıımadığı takdirde bütün şaraplar iyi bir yolculuk yaparlar" diyerck "La Sociologie Religieuse'yi" imtiyazlı bir konuma yükseltmek istedim. Ancak, bu genellemenin istisnaları. Gustaffson 'un İskandinavya'da ve Fichter'in ABD'de gerçekleştirdiği araştırmalardır. 1980'lerde görülen. "Kilise'nin Sınırlarını Genişletme Harcketi" ile "La Sociologie Religieuse" arasında doğrudan bir bağlantı olmamasına rağmen, iki oluşumun düşünce yapısında bazı ortak noktalar vardır. 
fonksiyonlara dikkat çekiyorlardı. Onların gündeminde yer alan başlıca konular şunlardı: Sivil din, dîni gruplar, din adamlarının rolü, Protestan ahlâkı ve ekonomik gelişme, mezheplerin kurumsallaşması ve dîni çoğulculuk.

3. 1960'lardan beri din sosyolojisinin İngilizce literatürüne egemen olan konulardan biri de sekülerleşme olgusudur. Bazı uzmanlar onu, rasyonalizasyon teorileri içerisinde değerlendirirken, diğer bazıları yapısal farkhlaşmaya ve hatta sosyal sektörler arasındaki ayrılığa dayandırmaktadır. Konuya farklı açılardan, ancak, geniş bir perspektiften yaklaşan bilim adamları arasında, Acquaviva (1966), Martin (1978), Fenn (1978), Dobbelaere (1981), Wilson (1982), Ferrarotti (1983), Hervieu-Leger (1986) ve Isambert (1986) gibi isimler sayılabilir. Sekülerleşme üzerine odaklanan büyük modernleşme teorileri, modern dünyada dînin önemini azaltma pahasına, sosyolojinin başlıca akımlarıyla bağlantılarını korumaya çalışmışlardır.

4. Peter Berger'in (1967) kutsal "âlemin" sosyal yapısı üzerine geliştirdiği ilerici teorilerin yanı sıra, Thomas Luckmann'ın (1967) dîni sosyalleşmenin doğası hakkında aynı derecede yenilikçi düşüncelerinin yarattı̆̆ "bilişsel" dönüşümün önemini abartmamak oldukça zordur. Onlar, birlikte ve ayrı ayrı gerçekleştirdikleri araştırmalarla, sadece sanayi toplumlarındaki Hrıstiyanlığın değil; aynı zamanda gelişmekte olan ülkelerdeki diğer dinlerin de ayırt edici özelliklerini çözümlemek için felsefî ve antropolojik yaklaşımlar geliştirdiler. Ayrıca, fenomenolojik yaklaşım, sosyoloji ve teoloji arasında sürüp giden tartışmalar için uygun koşulların yaratılmasına imkân sağlamıştır. Üstelik, erken dönem Hrıstiyanıı̆ı̆ı üzerine yapılan çalışmalara yeniden ilgi gösterilmesi, bir tür fenomenolojik din sosyolojisinin gelişimine katkıda bulunmuştur. Eleştirel teori ise, özellikle Almanca konuşulan toplumlarda, bazı neo-marksist fenomenologların ortaya çıkmasına yol açmıştır. Berger'in çalışmaları, çoğulcu toplumlarda, kilisenin meşrulaştırıcı ve meydan okuyucu etkisi karşısında, "aracı yapılar" olarak, yeni fikirlere ilham vermeye devam etmektedir. Luckmann'ın etkisi ise, özellikle, fenomenolojinin özelleştirilmesi ve dünya hayatı ile ilgili dinî konularda yürütülen araştırmalar üzerinde görülmektedir.

5. 1960'ların ortalarında, târihî maddeciliğin yapısalcılık ve fenomenolojiye doğru bir yönelim sergilemesiyle birlikte, dîni meseleler birçok Marksistin ilgi alanına girmeye başlamıştı. Açıkçası onlar, dinî kendi ideolojilerinin başlıkları altında tutmalarına rağmen, en azından Marksist indirgemeciliğin abartılı yükselişine izin vermiyorlardı. Bu, özellikle sanayi öncesi ve sanàyileşmekte olan toplumlarda dînin sosyal görünümünü yorumlamaya yönelik ciddî stratejiler olarak ortaya çıkmıştı (Maduro, 1982; Hautart, 1974; Hautart ve Lamercinier, 1983; Parker, 1986: Da Silva Costa, 1985; Thompson, 1986). Ayrıca bu durum, daha sonraları, sanayi toplumlarının sözde krizlerini yaşayan dîni ideolojiler üzerine geliş̧irilen teorilerin de habercisi oldu. Son yıllarda, dînin tarihi maddeciler tarafından yapılan değerlendirmeleri, eleştirel teoriyi savunanlar ile özgürlükçü, feminist ve çatışmacı teologlar arasında da görülmektedir. Bu tür neo ya da sözde 
Marksist bakış açılarının din sosyolojisi üzerinde doğrudan bir etkisi olmamıştır. Ancak, şunu unutmamalıyız ki, târihî maddecilik hem 1945'ten beri ciddî değişimler geçirmiş, hem de, günümüzde, sayıları gittikçe artan din sosyologlarından daha az eleştiri almaktadır.

Bütün bu büyük teorik yaklaşımların gözden geçirilmesi sonucu, iki tür mega teorik yaklaşım ortaya çıkmıştır. Birincisi, daha önce de işaret edildiği gibi, Luhmann (1977) ile Stark ve Bainbridge'in (1985) yoğun çabalarına rağmen, din sosyolojisi disiplinine hemen hemen hiçbir katkısı olmayan formel teoridir. Aile ya da eğitim sosyolojisi gibi alanlarla kıyaslandığında, orta boy teorilerin 1 şı̆̆ında test edilebilir hipotezler kurma girişimleri yok denecek kadar azdır ${ }^{18}$. Sonuçta, teorik perspektifler üzerine yoğun tartışmalar yapılırken, ampirik bulgular için aynı şeyleri söylemek mümkün değildir. İste bu nedenle, Marx, Durkheim, Weber (O'Toole, 1984), bazen Tröeltsch (Seguy, 1980) ve nadiren Simmel'in eserlerinden çıkarılan üst düzey teorik anlamların özenle işlenmesi, zamanla tüm alana egemen olmuştur. Bu tür klasiklere bağlılığın bir sonucu olarak, sanayi toplumunun ortaya çıkardığı soru ve sorunların ötesine geçme konusunda tereddütler yaşanmaktadır. Din sosyologları, geleneksel toplum, ileri sanayi toplumu, sanayi sonrası toplum, postmodern toplum ve geç kapitalist toplum gibi kavramlar üzerine teoriler geliştirmekte kısmen yavaş davranmışlardır (ancak bkz. Voye, 1985 ve Zylberberg, 1986). Ayrıca onlar, birkaç istisna dışında, sembolik etkileşimcilik, etnometodoloji, semiotik ve postmodernizmin çeşitli sonuçları gibi, post klasik perspektiflere de çok az ilgi göstermişlerdir.

İkincisi, İkinci Dünya Savaşı'ndan günümüze kadar geçen dönemde, dinîn duygu boyutuna gereken hassasiyet gösterilmediği hâlde, dinî hayatın tecrübî boyutlarına karşı gün geçtikçe artan bir duyarlılık sergilenmiştir. Ayrıca bu hususta, din sosyologları ile diğer sosyologlar arasında bir fark yoktur. Bu, insanları derinden etkileyen bir konunun araştırılmasında görülen çok önemli bir eksikliktir. Dîni duygulara, sadece pentakostalizm ve dinden dönme olgusu üzerine yapılan araştırmalarda yoğun bir şekilde rastlanılmaktadır. Din sosyolojisi, manevî hazlar ve ruhun ızdırapları gibi konulara da aynı derecede duyarsız kalmıştır. Aslında, din bilimcilerin, dînin duygu boyutuna gösterdikleri ilginin azaldı̆̆ını ya da sosyologların dînin bu boyutunu "elde tutmak" için uygun metotlar geliştiremediklerini itiraf etmek son derece kaygı vericidir. Ancak, bu noktada tek tesellimiz, artık din psikologlarının duyguları inceleme konusunda sosyologlardan daha başarılı olmalarıdır (bkz.Van Belzen ve Van Der Lans, 1986).

\section{Sonuçlar}

1945 'ten beri çeşitli şekillerde dile getirilen din sosyolojisi kaprisleri vardır. İfadeleri fazlasıyla abartılı olmasına rağmen, bazı uzmanlar, "gü-

\footnotetext{
${ }^{18}$ Örneğin, FERES Enstitüleri'nin benzer araştırmalar için genel hipotezler geliştirme girişimlerinin başarısızlıkla sonuçlanması, Holl (1970: 466)'u kaygılandırmıştı.
} 
nümüzde din sosyolojisinin sonsuz bir vasatlıklar denizi" olduğunu iddia etmektedir (Mol, 1985: 95). Bu durum, saygı duydukları üstatlarının yarattığı hayal kırıklığından bir an önce kurtulmak isteyen bazı din sosyologlanı için de sürekli bir gerilim kaynağı olmuştur.

Bununla birlikte, din sosyolojisinin klasik kuramcılarını, günümüzde, büyük oranda önemini kaybeden sanayi toplumunun hazırlayıcısı ve yorumlayıcısı olarak değerlendirenler vardır. Üstelik, onlar, yeni sosyal düzene, ileri sanayi toplumu, sanayi ötesi toplum, geç kapitalist, postmodern ve global toplum gibi isimler verme konusunda birbirleriyle yarışmaktadır. Ancak, hiç birisi, dinîn 19. yüzyılın sonlarında bulunduğu konumdan çok daha farklı bir yerde durduğunu itiraf etmeye yanaşmamaktadır. Ayrıca, din sosyologları, sanayileşme ve modernleşmenin şiddetli sancılarını yaşayan üçüncü dünya ülkelerinin dîni kurumlarında meydana gelen değişimler karşısında artan bir duyarlılık sergilemektedirler. Dolayısıyla, artık, eski teorilere özlem duymanın, eski tanrılara ve tanrıçalara özlem duymaktan bir farkının olup olmadığı tartışılmaya başlanmıştır.

Din sosyologları, klasik teori ve problemlere bağlılığın boyutları üzerindeki parçalanmışlıklarını hâlâ sürdürmelerine rağmen, bana öyle geliyor ki, onlar, 1945 sonrasında dînin sosyolojik açıdan çok daha problematik ve tartışmalı bir alan olduğu konusunda hemfikirdirler. Kamusal alanda çoğu dîni organizasyonun görünürlüğünün azalmasına karşın bireysel dindarlığın yükselişe geçmesi; din ve diğer kültür elemanları arasındaki farklılaşma ile dîni tekelciliklerin erozyonu gibi hususlar, sosyal anlamda dînin öneminde bir azalma olduğunun bir kanıtı olarak değerlendirilebilir. Ancak, sosyologlar arasında, adalet, barıs, biyo-medikal etik ve ulusların kendi geleceğini belirleme hakkı gibi konular üzerinde cereyan eden sosyal içerikli tartışmaların dinî boyutlarına ilginin her geçen gün arttığı görülmektedir. Ayrıca, onlar, yasal amaçlar doğrultusunda dînin yorumlanması, dîni özgürlügün sınırları, din-devlet ilişkileri ve hatta eğitim müfredatının içeriği gibi hususlarda yapılan dîni tartı̧̧maların sosyal önemini de gittikçe daha iyi kavramaktadır. Bazı din sosyologları ise, bu tür tartışmalara aktif olarak katılmaktadır.

1945'li yıllarda sosyologların yoğun bir gündemle tartıştığı dînin sosyal fonksiyonlarının bile, artık, gündem dışı kaldığı iddia edilebilir. Ne var ki, çağdaş bağlamı içerisinde dînin önemi gün geçtikçe artmaktadır. Böyle bir sonuç belki çok spekülatif bulunabilir. Ancak, şuna bütün kalbimle inanıyorum ki; şimdilerde sekiz yılda bir düzenlenen CISR/ICSR ile yeni kimliğine alışmakta olan Uluslararası Din Sosyolojisi Topluluğu (International Society for the Sociology of Religion / Societe Internationale de Sociologie des Religions), bu alanda yeni yaklaşımların öncüsü olacaktır. 


\section{BIBLIYYORAFYA}

Acquaviva, S., 1996, L'eclisi del sacro nella civilta industriale, Milano, Edizioni di Communita

Adriance, M.ve D.Blanshard, 1987, Syllabi and Instructional Materials for the Sociology of Religion, Washington, DC, American Sociological Association.

Almerich, P., 1965, "The Present Position of Religious Sociology in Spain", Social Compass 12, ss. 312-20.

Alston, J. P., 1977, “Availability of Archival Data in Sociogy of Religion Resarch",

Review of Religious Resarch 18 (3), ss. 233-43

Barker, E., 1984, The Making of a Moonie, Oxford, Blackwell.

Beckford, J. A., 1983, "The Restoration of "power'to the Socilogy of Religion",

Socilogical Analysis 44 (1). ss. 11-31

Beckford, J. A., 1985, "The Insulation and Isolation of the Sociology of Religion"

Sociological Analysis 46 (4) ss. 347-54

Beckford, J. A., 1989, Religion and Advanced Industrial Societies, London. Unwin Hyman.

Van Belzen, J. A. ve J. M. van der Lans (editörler), 1986, Current Issues in the

Psychology of Religion in Europe, Amsterdam, Rodopi

Berger, P. L., 1967, The Social Reality of Religion, Garden City, NJ, Doubleday.

Bibby, R., 1987, Fragmented Gods: the Poverty and Potential of Religion in Canada, Toronto, Irwin.

Birnbaum, N., 1960, "The Sociology of Religion at the Fourth World Congress of

Sociology ", Archives de Sociologie des Religions, 9, ss. 111-12

Birnbaum, N., 1961, "Nuffield College Conference on the Sociology of Religion", Archives de Sociologie des Religions 11, ss. 147-8

Blasi, A. ve M. Cuneo, 1986, Issues in the Sociology of Religion: A Bibliography. New York, Garland Press.

Boulard, F. ve J. Remy, 1968, Pratique religieuse urbaine et regions culturelles,

Paris, Editions Quvrieres.

Bourdieu, P.,1971, "Genese et structure du champ religieux", Revue française de Sociologie 12 ss. 295-334.

Bourdieu, P., 1987, "Sociologues de la croyance et croyances de sociologues", Archives de Sciences sociales des Religions 63(1), ss. 155-61.

Brathers, J., 1964, "Recent Developments in the Sociology of Religion in England and Wales", Social Compass 11 (3-4), ss. 13-19.

Campiche, R., 1971, "La sociologie de la religion en Suisse", Archives de Sociologie des Religions 32, ss. 165-79.

Carrier, H. ve E. Pin, 1964, Sociologie du Christianisme: Bibliographie internationale, Rome.

Cipriani, R., 1989, "Diffused Religion' and New Values in Italy", J. A. Beckford ve T. Luckmann (editörler) The Changing Face of Religion içinde, ss. 42-48, London, Sage.

Comite de Redaction, 1971, "Du GSR a un ISSR", Archives de Sociologie des Religions 31 (1), ss. 3-6. 
Conference Internationale de la Sociologie des Religions, 1978, Proceedings of the Tokyo Meeting of the CISR, Tokyo.

Da Silva Costa, M., 1985, Religion et Ideologie dans l'Instauration de la Paysannerie parcellaire du Nord du Portugal, Louvain-la-Neuve, Centre de Recherches Socio-Religieuses

Daiber, K. F ve T. Luckmann (editörler), 1983, Religion in den Gegenwartsströmungen der deutschen Soziologie, München, Chr. Kaiser Verlag.

Deelen, G. J., 1967, "La sociologie religieuse au Bresil", Social Compass 14 (1), ss. 53.7

Desroche, H., 1965, "D'une Decennie a l'auter: de la sociographie de la pratique religieuse a une pratique de la sociologie des religion", Archives de Sociologie des Religions 20, ss. 3-6

Desroche, H., 1971, "Une etape", Archives de Sociologie des Religions 32, ss. 3-8

Desroche, H. ve J. Seguy (editörler), 1970, Introduction aux Sciences humaines des Religions, Paris, Editions Cujas.

Dobbelaere, K., 1968, "Trend Report on the State of the Sociology of Religion", Social Compass 15 (5), ss. 329-65.

Dobbelaere, K., 1981, "Secularization: A Multi-dimensional Concept", Current Sociology 29 (2), ss. 1-21.

Drehsen, V., 1980, "Selected Bibliogrphy Referring to German Sociology of Religion and Church after 1945", Social Compass 27 (1) ss. 101-57.

Eister, A. W., 1965, "Emprical Research in Religion and Society: A Brief Survey of Some Fruitful Lines of Inquiry", Review of Religious Research 6(3), ss. 125 30 .

Estruch, J., 1976, "Sociology of Religion in Spain: A Critical Review", Social Compass 23 (4), ss. 427-38.

Fenn, R. K., 1978, Toward a Theory of Secolarization, Storrs, CT, Society for the Scientific Study of Religion.

Ferrarotti, F., 1983, Il paradiso del sacro, Bari, Laterza.

Fischer, W. ve W. Marhold, 1980, "The Concept of Symbolic Interactionizm in the German Sociology of Religion", Social Compass 27 (1), ss. 75-84.

Fogarty, M. P., 1957, Christian Democracy in Western Europe, 1820-1953. South Bend, IN, University of Norte Dame Press.

Foucart, E., 1982, "Sectes et mouvements religieux de l' Occident contemporain", Etudes et Documents en Sciences de la Religion, Quebec, Universite de Laval.

Friedrichs, R., 1974, "Social Research and Theology: the End of Detente?", Review of Religious Research 15 (3), ss. 113-27.

Fürstenberg, F. ve I. Mörth, 1979, "Ausgewahlte Literatur zur Religionssoziologie", Handbuch der empirischen Sozialforschung, Vol.14, Stuttgart.

Goddijn, W. ve F. Houtart, 1983, "Social Compass: Thirthy Years of Publishing in the Field of Sociology of Religion", Social Compass 30 (4), ss. 401-8.

Gombrich, R., 1971, Precept and Practice: Traditional Buddhism in the Rural Highlands of Ceylon, Oxford, Clarendon Press. 
Gustaffson, B., 1965, "The State of Sociology of Protestantism in Scandinavia", Social Compass 12, ss. 359-65.

Gustaffson, J. M., 1959, "Sociology of Religion in Sweden", Review of Religious Research 1 (3), ss. 101-9.

Hadden, J. K., 1974, “A Brief History of Religious Research Association”, Review of Religious Research 15 (3), ss. 128-36.

Hervieu-Léger, D., 1986, Vers un nouveau Christianisme?, Paris, Cerf.

Hervieu-Léger, D., 1987, "Faut-il définir la religion?", Archives de Sciences sociales des Religions 63 (1), ss. 11-30.

Highet, J., 1964, "A review of Scottish Socio-religious Research", Social Compass 11 (3-4), ss. $21-4$.

Highet, J., 1966, "Trend Report on the Sociology of Religion in Scotland", Social Compass 13(3), ss. 343-8.

Holl, A., 1970, "Socio-religious Research in Europe:a Report on the Activities of the Eleven Institutes in Eight European Countries", Social Compass, 17(3), ss. 461-8.

Homan, R., 1986, The Sociology of Religion: A Bibliographical Survey, Westport, CT, Greenwood Press.

Houtart, F., 1974, Religion and Ideology in Sri Lanka, Bangalore, TPI.

Houtart, F. ve G. Lemerciner, 1984, Hai Van: Life of a Vietnames Commune, London, Zed Press.

Isembert, F.-A., 1986 "Le désenchantement'du monde:non sens ou renouveau du sens", Archives de Sciences sociales des Religions 61(1), ss. 83-103.

Laeyendecker, L., 1967, "The Sociology of Religion in the Netherlands since 1960", Social Compass 14 (1), ss. 58-66.

Laeyendecker, L., 1984, "The Sociology of Religion: deficiences and Opportunities", Social Compass 31 (2-3), ss. 157-68.

Lalive d' Epinay, C., 1969, Haven of the Masses, London, Lutterworth Press.

Le Bras, G., 1956, “Sociologie des Religions”, Current Sociology 5 (1), ss. 15-17.

Lemercinier, G., 1983, Religion and Ideology in Kerala, Louvain-la-Neune, Centre de Recherches Socio-Religieuses.

De Loor, H. D., 1983, "The Sociology of Religion and the Dutch Churches since World War II", Social Compass 30 (4), ss. 25-39.

Luckmann, T., 1967, The Invisible Religion, New York, Mac Millan.

Luhmann, N., 1977, Funktion der Religion, FrankfurtMain, Suhrkamp.

Lukatis, I. ve H. Krebber, 1980, "Recherches empiriques concernant la religion en Allemagne Federale, Autriche et Suisse allemanique", Social Compass 27 (1), ss. $85-100$.

Maduro, O., 1982, Religion and Social Conflict, Maryknoll, NY, Orbis.

Maitre, J., 1967, "Sixieme congres mondial de sociologie", Archives de Sociologie des Religions 23 (1), ss. 19-21

Majka, J., 1968, "Communication sur les recherches socio-religieuses en Pologne", Social Compass 15 (3-4), ss. 285-91.

Martin, D. A., 1967, A Sociology of English Religion, London, Heinemann. 
Martin, D. A., 1978, A Gerieral Theory of Secularization, Oxford, Blackwell.

Mensching, G., 1947, Soziologic der Religion, Bonn.

Moberg, D. O., 1960, "Sociology of Religion in the Netherlands", Review of ReligiousResearch 2 (1), ss. 1-7.

Moberg, D. O., 1966a, "Some Trends in Sociology of Religion in the USA", Social Compass 13 (3), ss. 237-43.

Moberg, D. O., 1966b, "The Sociology of Religion in Western Europe and America”, Social Compass 13 (3), ss. 193-204.

Moberg, D.O., 1974, "Characterictics and Perspectives of Religious Research Association Constituenrs “, Review of Religious Research 15 (3), ss. 172-8.

Mol, H., 1985, "Review of Roy Wallis The Elementary Forms of the New Religious Life", Review of Religious Research 27 (1), ss. 94-5.

Montminy, J. P., ve S. Crysdale, 1974, La Religion au Canada: Bibliographie annottee, Quebec Presses de l' Universite de Laval.

Newman, W. M., 1974. "The Society for the Scientific Study of Religion: The Development of an Academic Society", Review of Religious Research 15 (3), ss. 137-51.

Nottingham, K ., 1954, Religion and Society, Garden City, NY, Doubleday.

O'Dea, T., 1966, The Sociology of Religion, Englewood Cliffs, NJ, Prentice-Hall.

Orsolic, M., 1973, "La sociologie de la religion d'inspiration marxiste en Yougoslavie", Social Compass 20 (1), ss. 73-82.

O’Toole, R., 1984, Religion: Classic Sociological Approaches, Toronto, McGrawHill-Ryerson.

Pace, E., 1987, "New Paradigms of Popular Religion”, Archives de Sciences sociales des Religions 64 (1), ss. 7-14.

Parker, C., 1986, Religion y Clases Subalternas en una Sociedad Dependiente, Louvain-la Neuve, Centre de Recherches Socio-Religieuses.

Parsons, T., 1966, "Religion in a Modern Pluralistic Society", Review of Religious Research 7 (3), ss. 125-46.

Pereira de Queriroz, M. I. 1981, "Evolution et creation religieuses: les cultes AfroBresiliens", Diogene 115, ss. 3-24.

Pickering, W. S. F., 1985, "Protestanism and Power: Some Sociological Observations", Social Compass 32 (2-3), ss. 163-74.

Poblete, R., 1960, "A Sociological Approach to the Sects", Social Compass 1 (5-6), ss. 383-406.

Pope, L., 1942, Millhands and Preachers, New Haven, CT, Yale University Press.

Prandi, C., 1977, "Religions et classes subalternes en Italie", Archives de Sciences sociales des Religions 43 (1), ss. 93-139.

Presler, H. H., 1961, "Sociology of Religion in India", Review of Religious Research 3 (2), ss. 97-113.

Reinders, J. E. ve G. E. Welz, 1972, "Bibliography on the Sociology of Religion in South Africa", Social Compass 19 (1), ss. 103-16. 
Richardson, J. T., 1985, "The Active vs. Passive Convert: Paradigm Conflict in Conversion/ Recruitment Research", Journal for the Scientific Study of Religion 24(2), ss. 163-79.

Robbins, T., 1988, Cults, Converts and Charisma: The Sociology of New Religious Movements, London, Sage

Robbins, T. ve R. Robertson (editörler), 1987, Church-State Relation: Tensions and Transions, New Brunswick, NJ, Transaction Books.

Schreuder, O., 1966, "Sociologie religieuse et recherche socio-ecclesiastique au cours de la periode 1962-1964", Social Compass 13 (3), ss. 205-35.

Schroeder, W., 1971, "The Development of Religious Research in the United States: Retrospect and Prospect", Review of Religious Research 13 (1), ss. 2-12.

Seguy, J., 1980, Christianisme et Societe. Introduction a la Sociologie de Ernst Troeltsch, Paris, Cerf.

Seyfarth, C., 1980, "The West German Discussion of Max Weber's Sociology of Religion since the 1960s", Social Compass 27 (1). ss. 9-25.

Shippey, F. A. 1962, "1962 Conference on Sociology of Religion", Review of Religious Research 4(3), ss. 127-8

Snow, D. A. ve R. Machalek, 1984, "The Sociology of Conversion", Annual Review of Sociology, 10, ss. 167-90.

Stark, R. ve W. S. Bainbridge, 1985, The Future of Religion. Secularization, Revival and Cult Formation, Berkeley, CA, University of California Press.

Thompson, K., 1986, Beliefs and Ideology, Chichester, Ellis Horwood.

Tomka, M., 1981, "A Selected Bibliography of Sociological Studies on Religion in Hungary (1945-1979)", Social Compass 18 (1), ss. 125-41.

Vidich, A. ve S. Lyman, 1985, American Sociology, New Haven, CT, Yale University Press.

Visnanathan, S., 1986, "Bibliography on Social Analysis of Indian Religions", Social Compass 33 (2), ss. 285-97.

Vogt, E., 1966, "The Sociology of Religion in Norway", Social Compass 13 (4), ss. 439-41.

Voye, L., 1985, "Au-dela de la secularisation", Lettres Pastorales. Informations officielles du diocese de Tournai 1 (21), ss. 253-74.

Wach, J., 1944, Sociology of Religion, Chicago, University of Chicago Press.

Wach, J., 1945, "Sociology of Religion", G.Gurvitch ve W.E.Moore (editörler), Twentieth Century Sociology içinde, ss. 406-37, New York, Philosophical Library.

Wallis, R., 1984, The Elementary Forms of the New Religious Life, London, Routledge.

Warburton, T. R., 1977, "Religion, Sociology and Liberation", Review of Religious Research 19 (1), ss. 90-4.

Ward, C. K.,1964, "Socio-religious Research in Ireland", Social Compass 11 (3-4), ss. 25-9.

Whitman, L. B., 1964, "Religious Research in Europe", Review of Religious Research 6(1), ss. 2-6. 
Willems, E., 1964 "Protestantism and Culture Change in Brasil and Chile", W. D' Antonio ve F. Pike (editörler), Religion, Revolution and Reform içinde, ss. 91108 , London, Burns and Oates.

Wilson, B. R., 1982, Religion in Sociological Perspective, Oxford, Oxford University Press.

Wuthnow, R., 1988, "Sociology of Religion”, N. J. Smelser (editörler), Handsbook of Sociology, içinde ss. 473-509, Beverly Hills, CA, Sage.

Yanagawa, K. ve Y. Abe, 1977, "Some Observations on the Sociology of Religion in Japan", Acts of the 14th CISR içinde, ss. 365-86 Lille, CISR.

Yinger, J. M., 1946, Religion in the Struggle for Power, Durham, NC, Duke University Press.

Zylberberg, J. (editörler), 1986, Masses et Postınodernite, Paris, Meridiens Klincksieck. 